\title{
Front Matter: Volume 10373
}

, "Front Matter: Volume 10373," Proc. SPIE 10373, Applied Optical Metrology II, 1037301 (30 November 2017); doi: 10.1117/12.2295987

SPIE Event: SPIE Optical Engineering + Applications, 2017, San Diego, California, SPIE. United States 


\title{
PROCEEDINGS OF SPIE
}

\section{Applied Optical Metrology II}

Erik Novak

James D. Trolinger

Editors

\author{
8-9 August 2017 \\ San Diego, California, United States
}

Sponsored and Published by

SPIE 
The papers in this volume were part of the technical conference cited on the cover and title page. Papers were selected and subject to review by the editors and conference program committee. Some conference presentations may not be available for publication. Additional papers and presentation recordings may be available online in the SPIE Digital Library at SPIEDigitalLibrary.org.

The papers reflect the work and thoughts of the authors and are published herein as submitted. The publisher is not responsible for the validity of the information or for any outcomes resulting from reliance thereon.

Please use the following format to cite material from these proceedings:

Author(s), "Title of Paper," in Applied Optical Metrology II, edited by Erik Novak, James D. Trolinger, Proceedings of SPIE Vol. 10373 (SPIE, Bellingham, WA, 2017) Seven-digit Article CID Number.

ISSN: 0277-786X

ISSN: 1996-756X (electronic)

ISBN: 9781510612037

ISBN: 9781510612044 (electronic)

Published by

SPIE

P.O. Box 10, Bellingham, Washington 98227-0010 USA

Telephone +1 3606763290 (Pacific Time) · Fax +1 3606471445

SPIE.org

Copyright (c) 2017, Society of Photo-Optical Instrumentation Engineers.

Copying of material in this book for internal or personal use, or for the internal or personal use of specific clients, beyond the fair use provisions granted by the U.S. Copyright Law is authorized by SPIE subject to payment of copying fees. The Transactional Reporting Service base fee for this volume is $\$ 18.00$ per article (or portion thereof), which should be paid directly to the Copyright Clearance Center (CCC), 222 Rosewood Drive, Danvers, MA 01923. Payment may also be made electronically through CCC Online at copyright.com. Other copying for republication, resale, advertising or promotion, or any form of systematic or multiple reproduction of any material in this book is prohibited except with permission in writing from the publisher. The CCC fee code is $0277-$ $786 \mathrm{X} / 17 / \$ 18.00$.

Printed in the United States of America.

Publication of record for individual papers is online in the SPIE Digital Library.

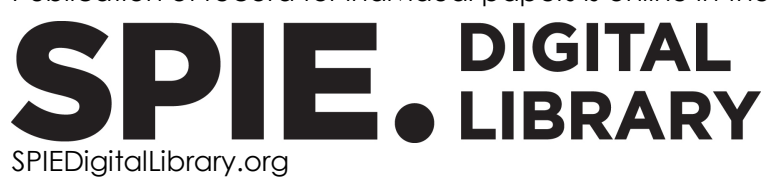

Paper Numbering: Proceedings of SPIE follow an e-First publication model. A unique citation identifier (CID) number is assigned to each article at the time of publication. Utilization of CIDs allows articles to be fully citable as soon as they are published online, and connects the same identifier to all online and print versions of the publication. SPIE uses a seven-digit CID article numbering system structured as follows:

- The first five digits correspond to the SPIE volume number.

- The last two digits indicate publication order within the volume using a Base 36 numbering system employing both numerals and letters. These two-number sets start with $00,01,02,03$, 04, 05, 06, 07, 08, 09, OA, OB ... 0Z, followed by 10-1Z, 20-2Z, etc. The CID Number appears on each page of the manuscript. 


\title{
Contents
}

\author{
vii Authors \\ ix Conference Committee \\ xi Introduction
}

SESSION 1 3D SHAPE MEASUREMENT

1037302 Usefulness of orthogonal basis sets for predicting optical performance of wavefronts with mid-spatial frequency error (Invited Paper) [10373-1]

1037304 Fusion of light-field and photogrammetric surface form data [10373-4]

1037305 Expansion of measurement area of three-dimensional deformation measurement speckle interferometry with same sensitivities in three directions under consideration of measurement sensitivity [10373-5]

1037306 Form and position measurement of sheet metal parts by boundary outlines extracting strategy [10373-6]

\section{SESSION 2 POLARIZATION MEASUREMENT AND TECHNIQUES}

1037307 Application of polarization in high speed, high contrast inspection [10373-7]

1037309 Measurement of polarization state of light using in-plane spin splitting [10373-9]

10373 OA The photonic spin Hall effect sensor [10373-10]

\section{SESSION 3 FINE SCALE FEATURE METROLOGY}

$10373 \mathrm{OB}$ Vibration-immune compact optical metrology to enable production-line quantification of fine scale features [10373-11]

10373 OC Experimental investigation of natural convection in a rectangular cavity with two protruded half cylinders using a Mach-Zehnder interferometer [10373-13]

10373 OD Authentication Sensing System Using Resonance Evaluation Spectroscopy (ASSURES) [10373-14]

$10373 \mathrm{OE}$ Optical mapping of surface roughness by implementation of a spatial light modulator [10373-15] 
10373 OG Dimensional metrology of micro structure based on modulation depth in scanning broadband light interferometry [10373-38]

\section{SESSION 4 OPTICAL TESTING}

$10373 \mathrm{OH} \quad$ Phase measuring deflectometry for determining 5 DOF misalignment of segmented mirrors [10373-16]

10373 Ol Deflectometry for measuring mount-induced mirror surface deformations [10373-17]

10373 0J General testing method for refractive surfaces based on reverse Hartmann test [10373-18]

10373 OK Geometrical error calibration in reflective surface testing based on reverse Hartmann test [10373-20]

$10373 \mathrm{OL} \quad$ Study of annular sub-aperture stitching interferometry for aspheric surfaces [10373-21]

SESSION 5 SPECTROSCOPIC TECHNIQUES AND METROLOGY

10373 OM Development of an oxygen saturation measuring system by using near-infrared spectroscopy [10373-22]

10373 ON Metrology of semiconductor structures using novel Fabry Perot fringe stretching system [10373-23]

1037300 Rapid, automated, quality control of diffraction grating efficiency [10373-24]

10373 OP Spatially and temporally resolved diagnostics of dense sprays using gated, femtosecond, digital holography [10373-25]

\section{SESSION 6 FRINGE PROJECTION AND STRUCTURED LIGHT}

10373 OQ Multimodal and synthetic aperture approach to full-field 3D shape and displacement measurements (Invited Paper) [10373-39]

10373 OR Focusing schlieren systems using digitally projected grids [10373-26]

10373 OS Application of instrument transfer function to a fringe projection system for measuring rough surfaces [10373-27]

10373 OT A three-dimensional scanning apparatus based on structured illumination method and its application in dental scanning [10373-28]

$10373 \mathrm{OU}$ A calibration method immune to the projector errors in fringe projection profilometry [10373-29] 
POSTER SESSION

10373 OV Collimator focus check with interferometer [10373-30]

10373 oW Characterizing the surface fluctuation of an epitaxial wafer by using a Shack-Hartmann wave-front sensor [10373-31]

$10373 \mathrm{OZ}$ Advanced polarization sensitive analysis in optical coherence tomography [10373-34]

1037310 Optical stabilization for time transfer infrastructure [10373-35]

1037312 Robust phase unwrapping algorithm for 3D profile measurement applications [10373-37]

1037313 Measurement of vibration using phase only correlation technique [10373-40] 
Downloaded From: https://www.spiedigitallibrary.org/conference-proceedings-of-spie on 26 Apr 2023

Terms of Use: https://www.spiedigitallibrary.org/terms-of-use 


\title{
Authors
}

Numbers in the index correspond to the last two digits of the seven-digit citation identifier (CID) article numbering system used in Proceedings of SPIE. The first five digits reflect the volume number. Base 36 numbering is employed for the last two digits and indicates the order of articles within the volume. Numbers start with 00, 01, 02, 03, 04, 05, 06, 07, 08, 09, 0A, 0B...0Z, followed by 10-1Z, 20-2Z, etc.

\author{
Ahn, Jae Sung, OT \\ Altmann, Michal, 10 \\ Altmannova, Lada, 10 \\ Arai, Y., 05 \\ Aulbach, Laura, OE \\ Balachandar, S., 13 \\ Buckner, Benjamin D., OR \\ Burt, Travis C., 00 \\ Butkiewicz, Mark, $\mathrm{OH}$ \\ Chang, S. T., OV \\ Coyle, Laura E., Ol \\ Davies, Angela D., 02, OH, OS \\ Deng, Qinyuan, OG \\ Dimas, Dave, OD \\ Dioumaev, Andrei K., OD, OP \\ Du, Jinglei, 09, 0A \\ Dunn-Rankin, Derek, OP \\ Eom, Joo Beom, OT \\ Evans, Christopher J., 02, OH, OS \\ Fan, Jingjing, 06 \\ Fang, Meiqi, 12 \\ Fisher, Mark R., 00 \\ Frater, Eric H., Ol \\ Ganesan, A. R., OC \\ Gong, Zhidong, OJ, OK \\ Guo, Hongwei, OU \\ Havlis, Ondrej, 10 \\ Horvath, Tomas, 10 \\ Hosseinimakarem, Zahra, 02 \\ $\mathrm{Hu}$, Song, OG \\ Huang, T. M., OV \\ Hula, Miloslav, 10 \\ Kim, Ju Wan, OT \\ Koch, Alexander W., OE \\ Kong, Ming, OJ, OK \\ Kono, K., OM \\ Krishnan Maliackal, Akhil, OC \\ Kujawińska, M., OQ \\ Kundrat, Jan, 10 \\ Lal, Amit K., OD \\ Leach, Richard K., 04 \\ Lee, Byeong $\mathrm{Ha}$, OT \\ L'Esperance, Drew, OR \\ $\mathrm{Li}$, Yongqian, 06 \\ Li, Zhaoxue, 09 \\ Liang, Rongguang, OJ, OK \\ Lin, Y. C., OV \\ LU, Min, OE
}

Ma, Liqun, 06

Ma, Yueyang, 12

Mani, Annamalai, OC

Minniti, Marco, OP

Mo, Linhai, OJ, OK

Mo, Shuhui, OJ, OK

Morita, Y., OM

Munster, Petr, 10

Nakamachi, E., OM

Novak, Erik, OB

Novak, Matthew J., 07

Park, Anjin, OT

Piano, Samanta, 04

Pöller, Franziska, OE

Pravdivtsev, Alexander, ON

Qiu, Xiaodong, 09

Radil, Jan, 10

Sims-Waterhouse, Danny, 04

Sitnik, R., OQ

Skoda, Pavel, 10

Slapak, Martin, 10

Smotlacha, Vladimir, 10

Strqkowski, Marcin R., OZ

Tang, Yan, OG

Trolinger, James D., OD, OP

Tsay, H. L., OV

Vann, Trent, $\mathrm{OH}$

Velc, Radek, 10

Vipin, K., 13

Vohnout, Rudolf, 10

Vojtech, Josef, 10

Walecki, Wojtek J., ON

Wang, Chao, OK

Wang, Daodang, OJ, OK

Wang, Shengjia, $\mathrm{OE}$

Wieloszyńska, Aleksandra, OZ

Xiao, Zhaoxian, OL

Xie, Linguo, OA

Xie, Zhongmin, OJ

$X U$, Ping, OJ, OK

Yang, Pao-Keng, OW

Zhang, Bin, OS

Zhang, Chunwei, 12

Zhang, Hangying, OL

Zhang, Ruihua, OU

Zhang, Zhiyou, 09, 0A

Zhao, Hong, 12

Zhao, Jun, OJ, OK 
Zhao, Lixin, OG

Zhao, Zixin, OL

Zhou, Changquan, 12

Zhou, Yi, OG

Zhou, Zili, 06

Zhuang, Yao-Kai, oW

Ziaee, Ali, OP

Ziegert, John, OS 


\section{Conference Committee}

Program Track Chair

H. Philip Stahl, NASA Marshall Space Flight Center (United States)

Conference Chairs

Erik Novak, 4D Technology Corporation (United States)

James D. Trolinger, MetroLaser, Inc. (United States)

Conference Program Committee

Anand Krishna Asundi, d'Optron Pte. Ltd. (Singapore)

Angela Davies, The University of North Carolina at Charlotte (United States)

Peter J. de Groot, Zygo Corporation (United States)

Sen Han, University of Shanghai for Science and Technology (China)

Kevin G. Harding, GE Global Research (United States)

Pengda Hong, Lehigh University (United States)

Richard K. Leach, National Physical Laboratory (United Kingdom)

Kate Medicus, Optimax Systems, Inc. (United States)

Matthew J. Novak, Technical Optics, Inc. (United States)

Levent Onural, Bilkent University (Turkey)

Peter Roos, Bridger Photonics, Inc. (United States)

Toru Yoshizawa, 3D Associates (Japan)

Session Chairs

1 3D Shape Measurement

Erik Novak, 4D Technology Corporation (United States)

2 Polarization Measurement and Techniques

Kate Medicus, Optimax Systems, Inc. (United States)

3 Fine Scale Feature Metrology

Angela Davies, The University of North Carolina at Charlotte (United States)

4 Optical Testing

Pengda Hong, Lehigh University (United States)

5 Spectroscopic Techniques and Metrology

James D. Trolinger, MetroLaser, Inc. (United States)

6 Fringe Projection and Structured Light

Matt J. Novak, Technical Optics LLC (United States) 
Downloaded From: https://www.spiedigitallibrary.org/conference-proceedings-of-spie on 26 Apr 2023

Terms of Use: https://www.spiedigitallibrary.org/terms-of-use 


\section{Introduction}

The methods of optical metrology have advanced significantly since the times of the early interferometers of the late 19th century. Fast cameras and processing make a whole range of new methods available today for looking at everything from fine microstructures to large astronomical systems. The papers presented in this conference focused on optical methods beyond traditional white-light or monochromatic-laser interferometric methods to other optical means of making precision measurements. They discuss novel uses of polarization, pattern projection, deflectrometry spectroscopy, and other means to measure everything from fine semiconductor structures to aircraft components to subway tunnel geometry. We hope you enjoy the novel ways in which optical metrology is enabling various new applications and industries.

Erik Novak James D. Trolinger 
Downloaded From: https://www.spiedigitallibrary.org/conference-proceedings-of-spie on 26 Apr 2023

Terms of Use: https://www.spiedigitallibrary.org/terms-of-use 